\title{
The ethnomedicinal plants used for human ailments at Mojana Wodera District, central Ethiopia
}

\author{
MIKIYAS ABEBE \\ Department of Biology, Faculty of Natural and Computational Sciences, Woldia University. Woldia, Ethiopia. Tel. +251923102609 , \\ vemail: mikiamen27@gmail.com
}

Manuscript received: 10 September 2021. Revision accepted: 30 September 2021.

\begin{abstract}
Abebe M. 2021. The ethnomedicinal plants used for human ailments at Mojana Wodera District, central Ethiopia. Biodiversitas 22: 4676-4686. An ethnobotanical study was carried out from March 2020 to February 2021 in selected sites of Mojana Wodera District to assess, identifying, and document medicinal plants to treat human ailments. Purposely and volunteer sampling techniques were applied to select 73 practitioners. Of those, 10 practitioners were key informants. Data was collected from informants using semi-structured interviews, focus group discussions, participant observation, and walk-in-the-word. The collected data were entered into an excel spreadsheet for statistical analysis. ANOVA and t-test were applied to compare the knowledge of the informants in different groups. ICF and FL values were calculated to identify the most common human ailments and heal the potential of medicinal plants. The result showed that a higher average $(\mathrm{p}<0.05)$ was recorded for crucial informants, illiterate and higher aged group. Still, there was a significant difference between male and female informants $(\mathrm{p}=0.032)$ on knowledge of medicinal plants. A total of 45 medicinal plant species (41 genera and 27 families) were identified to treat 35 types of ailments. From this total, 15.6\% were endemic for Ethiopia. Family Euphorbiaceae was dominant (11.1\%) for this study. In the finding, the leaf was the most widely plant part which is used to prepare remedies (29.79\%), followed by root (28.72\%), and the most popular remedy preparation was pounding (31.18\%). A higher ICF value (0.78) was recorded for dermatological category ailments, and the highest FL (94.12\%) occurred for Laggera tomentosa, which was under the therapeutic category of the throat and respiratory.
\end{abstract}

Keywords: Ailments, ethnobotany, illiterate, key informants, pounding

Abbreviations : FL: fidelity level; ICF: informant consensus factor

\section{INTRODUCTION}

The term traditional knowledge is defined as the total of knowledge, skills, attitude, and experiences used in the protection of health as well as in the prevention, diagnosis, and improvement or treatment of physical and social imbalance, and relying exclusively on practical experience, and observation (Marsh et al. 2018). This practice passes verbally or in written form (Battiste 2016; Vansina et al. 2017).

People of different countries globally have indigenous knowledge of various medicinal plants based on the type of disease that occurred in their local environment and locally available plants with their effectiveness for specific ailments (Teka et al. 2020). The uses of traditional medicinal plants have significant advantages to cultural development, acceptability, economic affordability. In addition, these medicinal plants cure certain types of diseases compared to modern medicines (Belayneh and Bussa 2014; Aragaw et al. 2020).

In Ethiopia, about $80 \%$ of the people and $90 \%$ of livestock depend on traditional medicinal plants to heal different ailments (Asmare et al. 2018; Kidane et al. 2018). This is due to difficulties to gain modern medicine and facilities, high acceptance of the healer by the people, low cost of traditional medicine than modern medicine, and availability of traditional medicinal plants in their local environment for immediate action (Hailu et al. 2020).

Ethiopia reaches in biological resources and has about 6,500 species of higher plants, with approximately $12 \%$ endemic (Seid 2019; Wassie 2020). This gives good opportunities for the country where medicinal plants play a significant role in supporting the country's primary healthcare system. However, like other parts of the country, only a minor attempt has been made to explore and document medicinal plants and associated knowledge scientifically. Moreover, the indigenous knowledge of the people and medicinal plants in the study district are at risk by different factors such as an expansion of agriculture, habitat loss, deforestation, climate change, overexploitation, urbanization, and use of plants for firewood and charcoal, etc. In addition to this, the traditional knowledge of medicinal plants has mainly been stored in the aged people, and might been could cause for loss of this golden knowledge of the people in the new generation. In addition to this, no research has been conducted in the study district regarding medicinal plants used to treat human ailments. Thus, the current study aims to explore, identify and document medicinal plant species used to heal human ailments and to document traditional medicinal knowledge of the local people in the study district. 


\section{MATERIALS AND METHODS}

\section{Description of the study area}

The study was conducted in Mojana Wodera District, North Showa zone, Amhara region, central Ethiopia. It is $202 \mathrm{~km}$ far from the capital city of Ethiopia, Addis Ababa, and $72 \mathrm{~km}$ from the town of North Showa zone, Debre Brehan, in the north direction. The district is bordered with Menze Mama Mider in the north, Menze Lalo Mider in the North West and Menze Keya Geberieal in south, Basona Worena in west and Tarmaber district in the east (Figure 1). The administrative center of the study district is Sela Dingaye, and the elevation of the study district ranges between altitudes of 1459-3172 $\mathrm{m}$ above sea level. Traditionally, the study district is divided into three agricultural zones: Dega (28\%), Woyna Dega (69\%), and kola $(3 \%)$. The annual rainfall of the districts ranges from $800-1000 \mathrm{~mm}$, and the annual temperature ranges from 10 $18^{\circ} \mathrm{C}$.

\section{Demographic}

The district has a total population of 83814 (44,489 (53.08\% men) and 39325 (46.92\% women), of whom 7799 $(9.31 \%)$ are urban inhabitants. Most people's economic income depends on both crop production and livestock. Most people are followers of Ethiopian Orthodox Tewahedo Christianity (99.94\%), and the remaining $0.059 \%$ are followers of Protestantism.

\section{Informant selection}

A total of 73 (51 males and 22 females) informants were selected from seven district sites. Purposive and volunteer sampling techniques were applied to choose the representative general informants and key informants suggested by (Mitchell et al. 2018). The informants' age ranges from 17-85 years old (33 were between 17-39 years old; 24 were between the ages 40 and 59; the other 16 informants were 60 and above years old). In addition, a total of $10 \mathrm{key}$ informants were selected based on the information gotten from the community members, informants themselves, and elders about their better knowledge.

\section{Data collection}

An Ethnobotanical survey was conducted from March 19, 2020, to February 10, 2021 (in all seasons) to collect plant specimens in flowering and availability. The data were collected using semi-structured interviews, focus group discussions, participant observation, and walk-inthe-word with their local language, Amharic. Information regarding local names of medicinal plants, part of the plant used for medicine, gathering and preparation methods, the dosage used, diseases treated, route of application, use of the plant other than medicinal uses, and management methods were recorded at the spot. The collected data was dried, deep-frozen, and identified at the national herbarium of Ethiopia in Addis Ababa University.

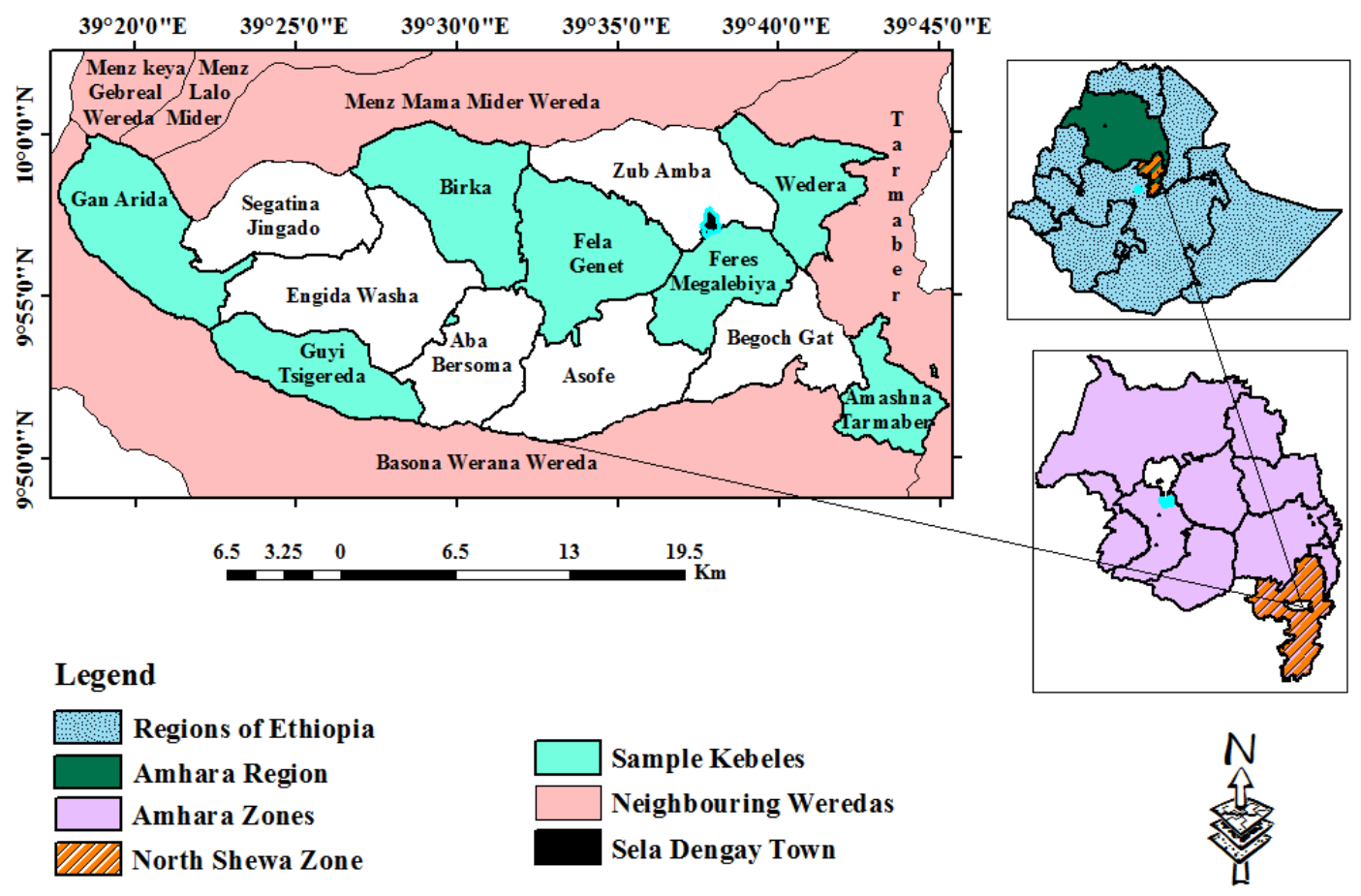




\section{Data analysis}

The data gained from informants were entered to excel spreadsheet software (Microsoft Corporation 2010) and organized for statistical analysis. The descriptive statistical method was employed to analyze and summarize the ethnobotanical data obtained from the interviews and observation, such as medicinal value, methods of preparation, application, disease treated, route of application, the dosage of medicine, and growth forms of and parts of the plants. Traditional knowledge differences between men and females, young and elder, illiterate and educated informants were analyzed using t-test and oneway ANOVA (SPSS software, version 20) at a 95\% confidence level. Informant Consensus Factor (ICF) values were applied to determine the most common human ailment categories that occurred in the district and identify potentially effective medicinal plant species in respective disease categories as mentioned by (Lulekal et al. 2013). The ICF was calculated as follows: Number of use citations in each category (nur) minus the number of species used (nt), and divided by the numbers of use citations in each category minus one (Cerqueira et al. 2020)

$$
\mathrm{ICF}=\mathrm{n}_{\mathrm{ur}-\mathrm{nt}} / \mathrm{n}_{\mathrm{ur}}-1
$$

Preference ranking was done to evaluate the effectiveness of certain medicinal plants against the most prevalent disease in the study district.

The relative healing potential of each identified medicinal plant were calculated by using the formula: $\mathrm{FL}=$ Ip/Iu $* 100$, where FL is fidelity level index, Ip is the number of informants who cited the importance of the species to treat a particular ailment, and $\mathrm{Iu}$ is the informants who cited the species for any ailments (Tounekti et al. 2019).

\section{RESULTS AND DISCUSSION}

Indigenous knowledge of the people to medicinal plants

Key informants reported significantly higher averages $(p<0.05)$ than general informants. Significance difference $(p<0.05)$ was observed in naming of medicinal plants between the illiterate informants and primary education informants; at the same time, there was also a significant difference $(\mathrm{p}<0.05)$ between informants of informal education and primary education informants. Illiterates and casual education informants could name more medicinal plants. But, there was no significant difference observed in other educational levels. There was a significant difference $(p<0.05)$ between the age groups to nominate medicinal plants. On average, the informants above 60 years were nominated a higher number of plants, followed by 40-59. Even though men informants reported more medicinal plants than females, there was no significant difference $(\mathrm{p}=$ 0.032 ) between the average reported by men and females.

\section{Diversity of medicinal plants}

A total of 45 medicinal plant species belonging to 41 genera and 27 families treated 35 human ailments. Family Euphorbiaceae was the leading $5(11.1 \%)$ Plant species, followed by family Asteraceae 4 (8.9\%) plants species. Family Lamiaceae, Rutaceae, and Solanaceae were represented by $3(6.7 \%)$ plants species each. The other 5 families (Aloaceae, Apocynaceae, Cucurbitaceae, Myrsinaceae, and Myrtaceae) were represented by 2 (4.4\%) species each, and the remaining seventeen families had a single species (Table S1).

\section{Growth habit and their habitat}

Regarding their growth form, herbs were the most harvested to treat human aliments and represented with 18 $(40 \%)$ species, followed by shrub $14(31.1 \%)$ and tree $11(24.4 \%)$ species, respectively. On the other hand, the climber was a minor plant habit $2(4.4 \%)$, used to treat human ailments in the study district (Figure 2). From the total of 45 plant species, $25(55.6 \%)$ plant species were obtained from the wild, 14 (31.1\%) from the home garden, and the remaining $6(13.3 \%)$ were obtained from both wild and home gardens (Figure 3).

\section{Endemics of the plants for Ethiopia}

Of the 45 plant species recorded in the study district, 28 (62.2\%) plants species were indigenous to Ethiopia, and the other $10(22.2 \%)$ plant species were introduced. The remaining $7(15.6 \%)$ plants species were Endemic for Ethiopia.

\section{Parts of plants used to prepare remedies}

In the study district, the most widespread plant parts used to prepare remedies was leaf $(29.79 \%)$ followed by root $(28.72 \%)$, fruit $(15.96 \%)$, bulb $(6.38 \%)$, Latex $(5.32 \%)$, all parts $(4.26 \%)$ and seed (3.19\%) respectively. In addition, the reaming sap and stem were contributed for (2.13\%) remedies preparation while Bark and flower were contributed for $(1.06 \%)$ heals practice (Figure 4$)$.

\section{Mode of preparation and routes of administration}

Various methods of remedy preparation were employed by the practitioners depending on the type of ailments. The most popular mode of remedy preparation was pounding (29 in frequency, 31.18\%), followed by smashing (15, $16.13 \%)$, squeezing $(10,10.75 \%)$, respectively (Figure 5). Regarding the routes of administration, the oral application was the most common type of administration $46(52.87 \%)$ followed by dermal 21(24.14\%), nasal $14(16.09 \%)$, anal $5(5.75 \%)$, and ocular $1(1.15 \%)$ respectively (Table S1).

\section{Dosage and antidotes}

In the study district, the practitioners did not use standardized measurement units even though they are used different traditional measurement methods such as SHEKENA, SENE, SENZER, etc. In addition, the system of the measurement varies depending on the age and sex of patients. 


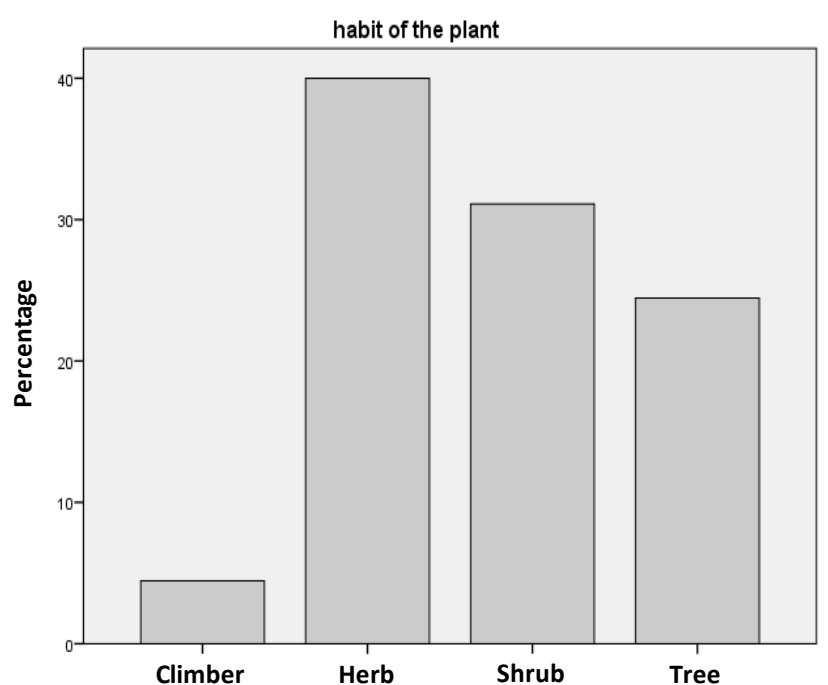

Figure 2. The habit of the plant

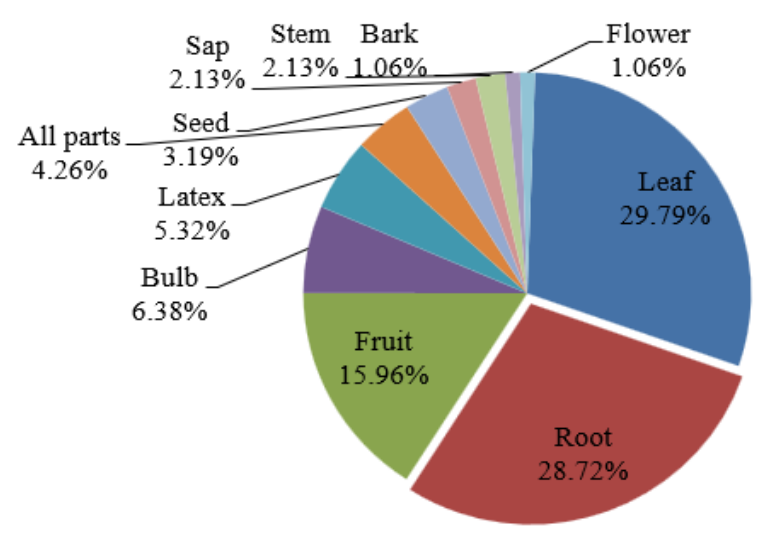

Figure 4. Plant parts used to treat human ailments

\section{Marketable medicinal plants}

A survey took place in five local markets of the district (Seladingaye 01, Sasit, Asofe, Begochgate, and Tarmaber). The result showed that, from the total of 45 plant species, $26(57.78 \%)$ were marketable. Out of these $26(57.78 \%)$, medicinal plant species were reported as commercial; only $4(15.38 \%)$ species (Echinops kebericho, Embelia schimperi, Hagenia abyssinica, and Lepidium sativum) were sold and purchased entirely for medicinal purposes. The remaining $84.62 \%$ were sold for various food, fence, firewood, timber, beverage, spice, etc. (Table S1).

\section{Efficacy of medicinal plants}

From the total of 35 human ailments that occurred in the study district, 10 categories were identified based on humans' effects. Among these categories, the highest ICF value was recorded for the dermatological category (0.78), followed by gastrointestinal and parasitic disease and evil spirit with ICF values of 0.76 each. Conversely, the least ICF (0.5) value was recorded for musculoskeletal and

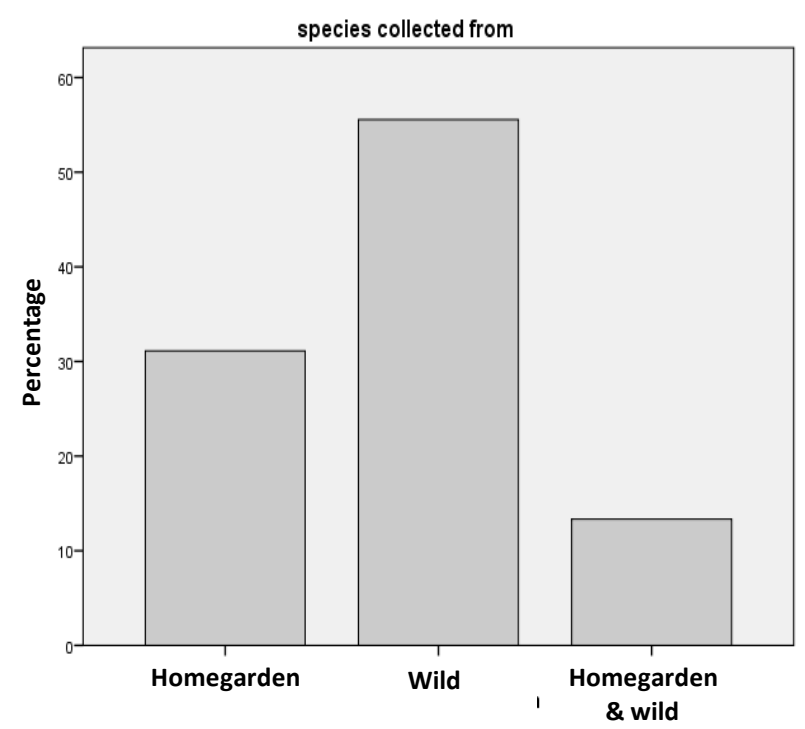

Figure 3. Habitat of the plant

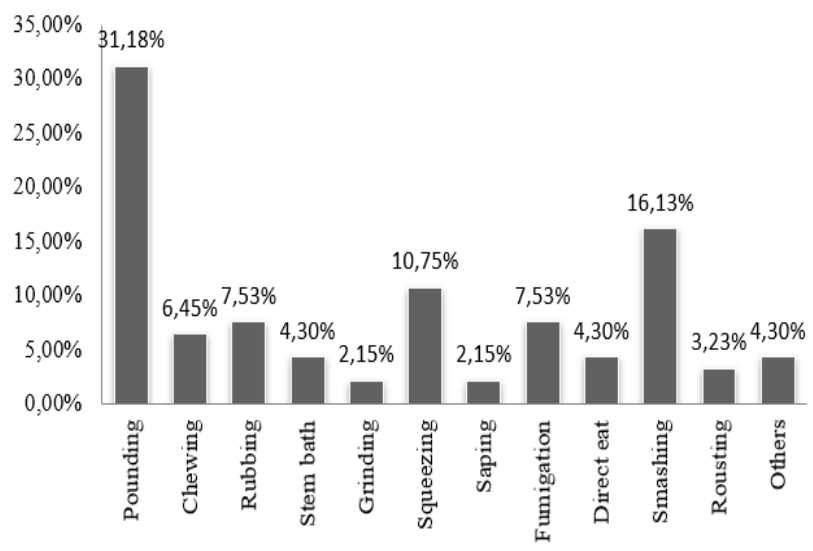

Figure 5. Mode of preparation of medicinal plants

nervous systems categories (Table 1).

\section{The healing potential of medicinal plants}

The highest fidelity level $(94.12 \%)$ was recorded for Laggera tomentosa, which was obtained under the therapeutic category of the throat and respiratory; followed by Capsicum annuum (93.75\%; obtained under gastrointestinal and parasitic), Carissa spinarum (91.67\%; obtained under animal bite disease), and Croton macrostachyus $(90.91 \%)$; under the therapeutic category of dermatology (Table 2).

\section{Preference ranking}

Based on the information obtained from 10 key informants, Acmella caulirhiza was the preferable medicinal plant to treat abdominal pain, the most frequently reported disease under the category of gastrointestinal and parasitic, followed by Ruta chalepensis and Thalictrum rhynchocarpum (Table 3). 


\section{Direct matrix method}

Direct matrix ranking (DMR) was done for 9 multipurpose medicinal plants to identify the most under pressure medicinal plants and the corresponding factor that threaten the plants. Accordingly, Olea europaea was the most threatened in this study, followed by Croton macrostachyus and Eucalyptus globulus. According to this study, the most factors for the exploitation of medicinal plants were firewood, construction, and charcoal, respectively (Table 4).

\section{Discussion}

A comparison of medicinal plant knowledge between communities was held. The result showed that a significant difference was observed between key and general informants. The cause for this higher difference could be the result of experience and the use of different references (Chekole 2017; Kidane et al. 2018). A significant difference was also observed between illiterate informants and primary education informants and informal education and primary education informants. The cause could be primary education informants did not give attention to traditional medicine. Instead, they prefer the modern types of medication in compression. The same finding was reported by (Eshete et al. 2016; Miara et al. 2018; Mbuni et al. 2020). Even though the average result varies in other groups of informants, it was not significant.

Table 1. Informant Consensus Factor (ICF) value of medicinal plants to treat human ailments in the study districts

\begin{tabular}{lccccc}
\hline Disease category & $\begin{array}{c}\text { No. of plant } \\
\text { species }\end{array}$ & $\begin{array}{c}\text { \% of plant } \\
\text { species }\end{array}$ & $\begin{array}{c}\text { Use } \\
\text { citations }\end{array}$ & \% use citations & ICF \\
\hline Dermatological & 15 & 33.33 & 64 & 22.54 & 0.78 \\
Gastrointestinal and parasitic diseases & 13 & 28.89 & 52 & 18.31 & 0.76 \\
Evil sprit & 6 & 13.33 & 22 & 7.75 & 0.76 \\
Throat and Respiratory & 14 & 31.11 & 54 & 19.01 & 0.75 \\
Animal bite disease & 9 & 20.00 & 32 & 11.27 & 0.74 \\
Bleeding and toothache & 5 & 11.11 & 14 & 4.93 \\
Mechanical injury & 3 & 6.67 & 7 & 2.46 & 0.69 \\
Febrile & 4 & 8.89 & 10 & 3.52 & 0.67 \\
Internal disease & 9 & 20.00 & 22 & 7.75 \\
Musculoskeletal and Nervous system & 4 & 8.89 & 7 & 0.62 \\
\end{tabular}

Table 2. Fidelity level of medicinal plants for a given ailments

\begin{tabular}{llccc}
\hline Medicinal plants & Therapeutic category & Ip & Iu & FL value \\
\hline Croton macrostachyus & Dermatological & 20 & 22 & 90.91 \\
Capsicum annuum & Gastrointestinal and parasitic & 15 & 16 & 93.75 \\
Carissa spinarum & Animal bite disease & 11 & 12 & 91.67 \\
Allium sativum & Gastrointestinal and parasitic & 12 & 14 & 85.71 \\
Echinops kebericho & Evil sprit & 6 & 7 & 85.71 \\
Artemisia abyssinica & Evil sprit & 7 & 9 & 77.78 \\
Ocimum lamiifolium & Febrile & 4 & 6 & 66.67 \\
Verbascum sinaiticum & Animal bite disease & 10 & 12 & 83.33 \\
Laggera tomentosa & Throat and respiratory & 16 & 17 & 94.12 \\
Verbena bonariensis & Febrile & 4 & 5 & 80.00 \\
\hline
\end{tabular}

Table 3. Preference ranking of medicinal plants to treat abdominal plain

\begin{tabular}{|c|c|c|c|c|c|c|c|c|c|c|c|c|}
\hline \multirow{2}{*}{ Types of medicinal plants } & \multicolumn{10}{|c|}{ Informants labeled A to J } & \multirow{2}{*}{ Total } & \multirow{2}{*}{ Rank } \\
\hline & $\mathbf{A}$ & B & $\mathbf{C}$ & D & $\mathbf{E}$ & $\mathbf{F}$ & $\mathbf{G}$ & $\mathbf{H}$ & I & $\mathbf{J}$ & & \\
\hline Acmella caulirhiza & 8 & 6 & 5 & 8 & 5 & 6 & 5 & 8 & 4 & 6 & 61 & 1 \\
\hline Ruta chalepensis & 5 & 7 & 6 & 3 & 8 & 4 & 7 & 3 & 8 & 7 & 58 & 2 \\
\hline Thalictrum rhynchocarpum & 3 & 8 & 8 & 6 & 4 & 8 & 3 & 7 & 5 & 5 & 57 & 3 \\
\hline Capsicum апnиum & 7 & 1 & 3 & 7 & 3 & 5 & 1 & 6 & 7 & 8 & 48 & 4 \\
\hline Citrus aurantiifolia & 6 & 4 & 2 & 5 & 7 & 2 & 6 & 5 & 6 & 3 & 46 & 5 \\
\hline Allium sativum & 2 & 3 & 4 & 4 & 6 & 7 & 8 & 1 & 3 & 4 & 42 & 6 \\
\hline Carissa spinarum & 4 & 5 & 7 & 1 & 2 & 1 & 2 & 4 & 1 & 1 & 28 & 7 \\
\hline Lepidium sativum & 1 & 2 & 1 & 2 & 1 & 3 & 4 & 2 & 2 & 2 & 20 & 8 \\
\hline
\end{tabular}

Note: Scores in the table are based on their efficiency to cure abdominal pain. I.e., number 8 indicate high effectiveness, and 1 shows minor point according to the informants 
Table 4. Average DMR scores of 10 critical informants for 9 medicinal plants and their different uses with factors that threaten their exploitation

\begin{tabular}{|c|c|c|c|c|c|c|c|c|c|c|c|}
\hline Use diversity & 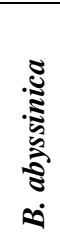 & 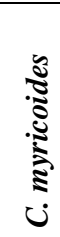 & 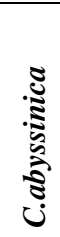 & 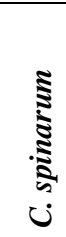 & 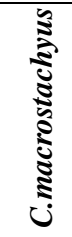 & 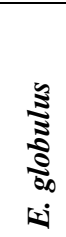 & 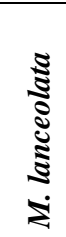 & 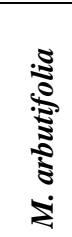 & 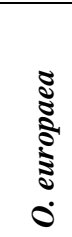 & Total & Rank \\
\hline Firewood & 4 & 4 & 5 & 5 & 4 & 5 & 4 & 5 & 5 & 41 & 1 \\
\hline Construction & 2 & 3 & 2 & 3 & 5 & 5 & 3 & 3 & 5 & 31 & 2 \\
\hline Charcoal & 3 & 2 & 3 & 4 & 5 & 5 & 4 & 2 & 2 & 30 & 3 \\
\hline Fence & 1 & 3 & 3 & 4 & 3 & 5 & 3 & 3 & 4 & 29 & 4 \\
\hline Medicinal & 2 & 3 & 4 & 4 & 5 & 2 & 3 & 3 & 3 & 29 & 4 \\
\hline Agricultural tool & 2 & 2 & 1 & 1 & 4 & 4 & 1 & 4 & 5 & 24 & 6 \\
\hline Food & 0 & 3 & 1 & 4 & 1 & 0 & 0 & 1 & 4 & 14 & 7 \\
\hline Total & 14 & 20 & 19 & 25 & 27 & 26 & 18 & 21 & 28 & & \\
\hline Rank & 9 & 6 & 7 & 4 & 2 & 3 & 8 & 5 & 1 & & \\
\hline
\end{tabular}

Note: 5: Best; 4: Very good; 3: Good; used; 1: lest used 0: no value.

This study also showed that a significantly higher average number of medicinal plants $(p<0.05)$ was reported by the age above 60 and 40-59. Generally, this finding revealed that the knowledge of medicinal plants declined from elder to younger informants. During the interview and collection of medicinal plants, the interest and belief of the elder informants to express their effectiveness were high. In contrast, the youngest informants showed low interest (Araújo et al. 2018). The main reason for this common interest of the youngest informants was an expansion of modern medication. Thus, decreasing positive attitude towards medicinal plants is an indication of the erosion of medicinal plants. The same finding was conducted in Tefera et al. (2019) and Azis et al. (2020). Regarding sex, the informants do not have significant differences in the naming of medicinal plants $(\mathrm{p}=0.032)$. This finding agrees with the result of Alalwan et al. (2019).

In the present study, a total of 45 medicinal plants and their uses were documented. This indicates the study district is reached in biodiversity. Regarding families, Euphorbiaceae and Asteraceae have accounted for the highest number (Temam 2019). This indicates that the availability of these families in the study district showed the family's effectiveness in treating different ailments compared to other families.

The high usage of herbs for medicinal plants to treat different health problems indicates the availability of herbs than trees and shrubs in the study district. The same finding was reported by (Giday et al. 2016). Out of the total listed medicinal plants in the study cites about $55.6 \%$ were obtained from the wild (Wondie 2018; Yohannis et al. 2018). In the study district, medicinal plants harvested from the wild are highly affected by factors such as the expansion of agriculture, urbanization, and natural elements. This causes the loss of many medicinal plants from the districts. In turn, this loss of medicinal plants causes the youngest practitioners' degradation of medicinal plant knowledge (Yohannis et al. 2018; Aman et al. 2020; Mosissa and Atinafu 2021).
The result showed that $77.8 \%$ of medicinal plants were endemic and indigenous to the country. This means the practitioners were familiar with the plant, which is available in their local area than exotic species. This indicated that the knowledge of medicinal plants is not recent; instead, it passes from generation to generation (Tuasha et al. 2018).

This study also revealed that leaf and root were the main plant parts used to treat human ailments (Araya et al. 2015). Using the leaf is simple to prepare and to extract the chemicals from it for remedies. At the same time, it has a more negligible effect on mother plants. The current study agrees with the work of (Ahmed et al. 2016). However, using root for preparation of remedies cause for loss of mother plants it will also cause for the local extinction of the plants. The same result was reported by (Agisho et al. 2014).

The result showed that the pounding method of remedies preparation was dominant for the study district, followed by the smashing method. Pounding method remedies preparation has a significant advantage in preserving it in powder, essential during the dry season. This finding coincided with the result by Gebre (2018), Demssie (2020), Taha and Woldeyohannes (2020). Regarding on mode of administration, the oral application was dominant, followed by dermal and nasal. Both oral and nasal routes of administration are considered to undergo rapid physiological reactions with the causative agents and increase the curative power of the remedies. This finding agrees with the result of Chenthamara et al. (2019). In addition to this, the herbalist applied the treatments on the skin if the illness was dermal. Most of the time, water is used to process the plants as universal solvents. However, some plant parts didn't require water to process.

Regarding the dosage of the remedies, the practitioners had their measurement tools, which were not scientific. This unscientific measurement could lead to erroneousness. However, the practitioners have used antidotes if the remedies hurt the patient. 
The result showed that about $42.22 \%$ of medicinal plants were not purchased for either medicinal or other uses in the district. Of the total of $57.78 \%$ marketable medicinal plants, only $15.38 \%$ were purchased for therapeutic value. The remaining $84.62 \%$ were available for different purposes other than medicinal value. The only medicinal plants purchased for traditional medicinal value were Echinops kebericho, Embelia schimperi, Hagenia abyssinica, and Lepidium sativum. This indicates that most medicinal plants are harvested from the wild when people want to use them for health care. Medicinal plants of the district are under pressure because the people use them for income generation and other uses in their homes. The current result agreed with the finding of (Lulekal et al. 2013).

Best agreements among informants on medicinal plants were reported to treat dermatological, gastrointestinal \& parasitic diseases and evil spirits, respectively (with ICF values of $0.78,0.76$, and 0.75 , respectively). The result assured that these diseases are frequent and familiar for the district. At the same time, it also confirmed the effectiveness of the listed medicinal plants to treat these ailments. In other words, the plants cited by critical informants were bioactive for ailments for the above disease.

The highest-fidelity levels for Laggera tomentosa $(94.12 \%)$ to treat throat and respiratory disease, Capsicum annuum (93.75\%) to treat gastrointestinal and parasitic disease, Carissa spinarum $(91.67 \%)$ to treat animal bite disease, and Croton macrostachyus (90.91\%) to treat dermatological disease. The highest value of fidelity level indicated the high healing potential of the plants to related diseases.

Abdominal pain was the most frequent disease in the districts. To treat this ailment, a total of 8 medicinal plants were used. Acmella caulirhiza was the most effective medicinal plant to treat abdominal pain, Ruta chalepensis, and Thalictrum rhynchocarpum. These medicinal plants also were more effective in treating other ailments. The result showed that the biochemical of the plants have the potential to treat other health.

According to the direct matrix ranking result, Olea europaea, Croton macrostachyus, and Eucalyptus globulus were the most threatened medicinal plant species. As a result, these multipurpose plants are exploited more for their nonmedicinal uses, such as firewood, construction, charcoal, etc. The benefits of medicinal plants for purposes other than their medicinal values have a significant effect on the survival of the plants. The same finding occurred in (Giday et al. 2003).

The district was reached in medicinal plants and endemic plant species diversity, but the attempt to conserve these medicinal plants and indigenous knowledge of the people was not significant. On the other hand, at the moment of expansion of agriculture, urbanization dramatically affects the survival of these medicinal plants in the district. So the district requires special attention from the government and stakeholders as well as the people are mandatory. It also suggested healers' association which professionals support, and the government should encourage in situ and ex situ conservation strategies for medicinal plants of the districts.

\section{ACKNOWLEDGEMENTS}

The author gratefully acknowledges the inhabitants, especially the informants of Mojana Wodera District, particularly the traditional medical practitioners who unreservedly shared their knowledge on medicinal plants. I would also extend my gratitude to the administrative office of Mojana Wodera Woreda, the agricultural office, the executive office of each selected site, and staff members of the biology department of Woldia University. I would also express my gratitude to Addis Ababa University for letting me use the national herbarium. Finally, the author declares that for this work, there is competing interest.

\section{REFERENCES}

Agisho H, Osie M, Lambore T. 2014. Traditional medicinal plants utilization, management and threats in Hadiya Zone, Ethiopia. J Med Plant 2 (2): 94-108.

Ahmed S, Ahmad M, Swami BL, Ikram S. 2016. A review on plants extract mediated synthesis of silver nanoparticles for antimicrobial applications: A green expertise. J Adv Res 7 (1): 17-28. DOI: 10.1016/j.jare.2015.02.007

Alalwan TA, Alkhuzai JA, Jameel Z, Mandeel QA. 2019. Quantitative ethnobotanical study of some medicinal plants used by herbalists in Bahrain. J Med Plant 17: 100278. DOI: 10.1016/j.hermed.2019.100278

Aman M, Dalle G, Asfaw Z. 2020. Richness, distribution and conservation status of medicinal plants in Tiyo District, Arsi Zone, Oromia, Ethiopia. J Med Plant 8 (4): 275-285.

Aragaw TJ, Afework DT, Getahun KA. 2020. Assessment of knowledge, attitude, and utilization of traditional medicine among the communities of Debre Tabor Town, Amhara Regional State, North Central Ethiopia: A cross-sectional study. Evid Based Complement Alternat Med 2020: 6565131. DOI: 10.1155/2020/6565131

Araújo KA, de Andrade Miranda IP, Camargo C, Repetto M. 2018. Knowledge of medicinal plants used by residents in two peripheral districts of Boa Vista, Roraima, Northern Brazilian Amazon: Phytotherapy as a new strategy in collective health. J Med Plant Res 12 (26): 435-447. DOI: 10.5897/JMPR2018.6634

Araya S, Abera B, Giday M. 2015. Study of plants traditionally used in public and animal health management in Seharti Samre District, Southern Tigray, Ethiopia. J Ethnobiol Ethnomed 11 (1): 1-25. DOI: 10.1186/s13002-015-0015-5

Asmare TW, Yilkal BA, Mekuannint T, Yibeltal AT. 2018. Traditional medicinal plants used to treat maternal and child health illnesses in Ethiopia: An ethno-botanical approach. J Tradit Med Clin Natur 7 (277): 2. DOI: $10.4172 / 2573-4555.1000277$

Azis S, Zubaidah S, Mahanal S, Batoro J, Sumitro SB. 2020. Local knowledge of traditional medicinal plants use and education system on Their Young of Ammatoa Kajang Tribe in South Sulawesi, Indonesia. Biodiversitas 21 (9): 3989-4002. DOI: 10.13057/biodiv/d210909

Battiste M. 2007. Research ethics for protecting indigenous knowledge and heritage: Institutional and researcher responsibilities. In: Denzin NK and Giardina MD (eds). Ethical Futures in Qualitative Research: Decolonizing the Politics of Knowledge. Left Coast Press.

Belayneh A, Bussa NF. 2014. Ethnomedicinal plants used to treat human ailments in the prehistoric place of Harla and Dengego valleys, eastern Ethiopia. J Ethnobiol Ethnomed 10 (1): 1-17. DOI: DOI: 10.1186/1746-4269-10-18

Cerqueira TMG, de Carvalho CAC, Dos SRV, Lemos RPL, da Silva SAS, Barreto E. 2020. The use of medicinal plants in Maceió, Northeastern Brazil: An ethnobotanical survey. Medicines 7 (2): 7 . DOI: 10.3390/medicines7020007 
Chekole G. 2017. Ethnobotanical study of medicinal plants used against human ailments in Gubalafto District, Northern Ethiopia. J Ethnobiol Ethnomed 13 (1): 1-29. DOI: DOI: 10.1186/s13002-017-0182-7

Chenthamara D, Subramaniam, Ramakrishnan SG, Krishnaswamy S, Essa MM, Lin FH, Qoronfleh MW. 2019. Therapeutic efficacy of nanoparticles and routes of administration. Biomater Res 23 (1): 1-29. DOI: 10.1186/s40824-019-0166-X

Eshete MA, Kelbessa E, Dalle G. 2016. Ethnobotanical study of medicinal plants in Guji agro-pastoralists, Blue Hora District of Borana Zone, Oromia region, Ethiopia. J Med Plants Stud 4 (2): 170-184.

Gebre T. 2018. Ethnobotanical study of traditional medicinal plants and the associated indigenous knowledge of Gamo people: The case of Bonke Woreda, Southern Ethiopia. Ethiop J Biol Sci 17 (1): 57-77.

Giday K, Lenaerts L, Gebrehiwot K, Yirga G, Verbist B, Muys B. 2016. Ethnobotanical study of medicinal plants from degraded dry afromontane forest in northern Ethiopia: Species, uses and conservation challenges. J Herb Med 6 (2): 96-104. DOI: 10.1016/j.hermed.2016.03.004

Giday M, Asfaw Z, Elmqvist T, Woldu Z. 2003. An ethnobotanical study of medicinal plants used by the Zay people in Ethiopia. J Ethnopharmacol 85 (1): 43-52. DOI: 10.1016/s0378-8741(02)003598

Hailu F, Cherie A, Gebreyohanni, T, Hailu R. 2020. Determinants of traditional medicine utilization for children: a parental level study in Tole District, Oromia, Ethiopia. BMC Complement Altern Med 20 (1): 1-11. DOI: 10.1186/s12906-020-02928-1

Kidane L, Gebremedhin G, Beyene T. 2018. Ethnobotanical study of medicinal plants in Ganta Afeshum District, Eastern Zone of Tigray, Northern Ethiopia. J Ethnobiol Ethnomed 14 (1): 1-19. DOI: 10.1186/s13002-018-0266-Z

Lulekal E, Asfaw Z, Kelbessa E, Van Damme P. 2013. Ethnomedicinal study of plants used for human ailments in Ankober District, North Shewa Zone, Amhara region, Ethiopia. J Ethnobiol Ethnomed 9 (1) 1-13. DOI: 10.1186/1746-4269-9-63

Marsh TN, Marsh DC, Ozawagosh J, Ozawagosh F. 2018. The sweat lodge ceremony: A healing intervention for intergenerational trauma and substance use. Int Indig Policy $\mathrm{J}$ 9: 2. DOI: 10.18584/iipj.2018.9.2.2

Mbuni YM, Wang S, Mwangi BN, Mbari NJ, Musili PM, Walter NO, Wang Q. 2020. Medicinal plants and their traditional uses in loca communities around Cherangani Hills, Western Kenya. Plants 9 (3): 331. DOI: 10.3390/plants9030331

Miara MD, Bendif H, Hammou MA, Teixidor-Toneu I. 2018 Ethnobotanical survey of medicinal plants used by nomadic peoples in the Algerian steppe. J Ethnopharmacol 219: 248-256. DOI 10.1016/j.jep.2018.03.011
Mitchell D, Raymond M, Jellett J, Webb-St Mart M, Boyd L, Botti M, Steen K, Hutchinson A, Redley B, Haines T. 2018. Where are falls prevention resources allocated by hospitals and what do they cost? A cross sectional survey using semi-structured interviews of key informants at six Australian health services. Int J Nurs Stud 86: 5259. DOI: 10.1016/j.ijnurstu.2018.06.002

Mosissa, D, Atinafu H. 2021. Applied ethnobotany: People, medicinal plants use and conservation practices in Benishangul Gumuz Regional State of Ethiopia: The future cursed natural resource in the Region. Int J Pharma Sci 1 (1): 18-30. DOI: 10.51626/ijps.2021.01.00003

Seid M. 2019. Critical solutions for critical problems: Threats to sustainable use and management of Nech Sar National Park (NSNP) in Ethiopia. Afr $\mathrm{J}$ Hosp Tour Leis 8: 1. DOI: 10.20546/ijcrar.2019.701.002

Taha E, Woldeyohannes MS. 2020. Herbalists and their mode of health care service delivery in debre Markos town, Northwest Ethiopia. Adv J Soc Sci 6 (1): 122-137. DOI: 10.21467/ajss.6.1.122-137

Tefera BN, Kim YD. 2019. Ethnobotanical study of medicinal plants in the Hawassa Zuria District, Sidama zone, Southern Ethiopia. J Ethnobiol Ethnomed 15 (1): 1-21. DOI: 10.1186/s13002-019-0302-7

Teka A, Asfaw Z, Demissew S, Van Damme P. 2020. Medicinal plant use practice in four ethnic communities (Gurage, Mareqo, Qebena, and Silti), South Central Ethiopia. J Ethnobiol Ethnomed 16: 1-12. DOI: 10.1186/s13002-020-00377-1

Temam TD. 2016. Ethnobotanical study of medicinal plants of MirabBadwacho District, Ethiopia. J BioSci Biotechnol 5 (2): 151-158.

Tounekti T, Mahdhi M, Khemira H. 2019. Ethnobotanical study of indigenous medicinal plants of Jazan Region, Saudi Arabia. Evid Based Complement Alternat Med 2019: 3190670. DOI: $10.1155 / 2019 / 3190670$

Tuasha N, Petros B, Asfaw Z. 2018. Medicinal plants used by traditional healers to treat malignancies and other human ailments in Dalle District, Sidama Zone, Ethiopia. J Ethnobiol Ethnomed 14 (1): 1-21. DOI 10.1186/s13002-018-0213-Z

Vansina J, Wright, HM, Leydesdorff S, Tonkin E. 2017. Oral tradition: A study in historical methodology. Routledge, London. DOI: $10.4324 / 9781315125855$

Wassie SB. 2020. Natural resource degradation tendencies in Ethiopia: A review. Environ Syst Res 9 (1): 1-29. DOI: 10.1186/s40068-02000194-1

Wondie A. 2018. Ecological conditions and ecosystem services of wetlands in the Lake Tana Area, Ethiopia. Ecohydrol Hydrobiol 18 (2): 31-244. DOI: 10.1016/j.ecohyd.2018.02.002

Yohannis SW. Asfaw Z, Kelbessa E. 2018. Ethnobotanical study of medicinal plants used by local people in Menz Gera Midir District, North Shewa Zone, Amhara Regional State, Ethiopia. J Med Plant Res 12 (21): 296-314. DOI: 10.5897/JMPR2018.6616 
Table S1. Additional file (scientific name, family name, local name, additional use, parts used, used to treat, mode of preparation and mode of application)

\begin{tabular}{|c|c|c|c|c|c|c|c|c|}
\hline $\begin{array}{l}\text { Code } \\
\text { no. }\end{array}$ & Scientific name & Family name & Local name & $\begin{array}{l}\text { Other } \\
\text { uses }\end{array}$ & $\begin{array}{l}\text { Parts } \\
\text { used }\end{array}$ & Used to treat & Preparation & $\begin{array}{l}\text { Taken } \\
\text { through }\end{array}$ \\
\hline \multirow[t]{2}{*}{ M4 } & Acmella caulirhiza \# & Asteraceae & Yemider & $\mathrm{M}$ & $\mathrm{R}$ & Abdominal pain & Direct chewing the fresh root & $\mathrm{O}$ \\
\hline & & & berebere & & $\mathrm{Fl}, \mathrm{R}$ & Tonsillitis & Chewing the root and flower & $\mathrm{O}$ \\
\hline \multirow[t]{2}{*}{ M5 } & Acokanthera schimperi & Apocynaceae & Merenze & M,SPI & $\mathrm{R}$ & Hemorrhoids & Pound the root and put it on the affected part. & An \\
\hline & (A.DC.) Schwein \# & & & & $\mathrm{L}$ & Tumor & $\begin{array}{l}\text { Extract liquid from the leaf by squeezing the } \\
\text { drink and spill on the affected part }\end{array}$ & $\mathrm{O}, \mathrm{Dr}$ \\
\hline \multirow[t]{6}{*}{ M19 } & Allium sativum * & Alliaceae & Nechi & FO, SPI, & $\mathrm{Bu}$ & Abdominal pain & Pound the bulb and mix with water and drink it & $\mathrm{O}$ \\
\hline & & & shenkurt & $\mathrm{M}$ & $\mathrm{Bu}$ & Evil eye & Chewing the bulb & $\mathrm{O}$ \\
\hline & & & & & $\mathrm{Bu}$ & Common cold & Peel the bulb and insert it in the hole of nose & $\mathrm{Na}$ \\
\hline & & & & & $\mathrm{Bu}$ & Granule & Cut bulb then rubbed on the affected part & Dr \\
\hline & & & & & $\mathrm{Bu}$ & Dandruff & Include in our daily food & $\mathrm{O}$ \\
\hline & & & & & $\mathrm{Bu}$ & Toothache & Pound and hold with teeth & $\mathrm{O}$ \\
\hline M11 & $\begin{array}{l}\text { Aloe pulcherrima Gilbert } \\
\text { and Sebsebe @ }\end{array}$ & Aloaceae & Sete eret & M & $\mathrm{Sa}$ & Snake bite & Take the sap with mouth & $\mathrm{O}$ \\
\hline M6 & Aloe trichosantha \# & Aloaceae & Wende eret & M & $\mathrm{Sa}$ & Snake bite & Take the sap with mouth & $\mathrm{O}$ \\
\hline \multirow[t]{3}{*}{ M8 } & Artemisia abyssinica \# & Asteraceae & Chiqugn & M & $\mathrm{L}$ & Evil eye & Sniff the fresh leaf & $\mathrm{Na}$ \\
\hline & & & & & $\mathrm{L}$ and $\mathrm{S}$ & Cough & Pound the leaf and stem then drink its extracts & $\mathrm{O}$ \\
\hline & & & & & $\mathrm{L}$ and $\mathrm{S}$ & Fever & Pound the leaf and stem then drink its extracts & $\mathrm{O}$ \\
\hline M10 & $\begin{array}{l}\text { Becium grandiflorum } \\
\text { (Lam.) Pic.Serm @ }\end{array}$ & Lamiaceae & Muatishe & FIW, M & $\mathrm{L}$ & Pneumonia & Pound the leaf; then extract the liquid and drink it. & $\mathrm{O}$ \\
\hline M7 & Bersama abyssinica \# & Melianthaceae & Azamer & FIW, M & $\mathrm{R}$ & Rabies & $\begin{array}{l}\text { Pound the root then drink the extract and put the } \\
\text { decoction on the bite site }\end{array}$ & $\mathrm{O}, \mathrm{Dr}$ \\
\hline \multirow[t]{4}{*}{ M9 } & Calotropis procera (Ait.) & Asclepiadaceae & Kinbo & $\mathrm{M}$ & $\mathrm{L}$ & Hemorrhoids & Rubbed the latex on the affected parts. & An \\
\hline & Airf \# & & & & $\mathrm{R}$ & Hemorrhoids & $\begin{array}{l}\text { Pound the root and incarceration on the affected } \\
\text { part }\end{array}$ & An \\
\hline & & & & & $\mathrm{La}$ & Wound & Take single oral dose dry latex & $\mathrm{O}$ \\
\hline & & & & & $\mathrm{La}$ & Wound & Put the latex on the affected part & Dr \\
\hline \multirow[t]{3}{*}{ M14 } & Capsicum аппиит L.* & Solanaceae & Berbere & FO, & Fr & Abdominal pain & Grind it and drink it with water & $\mathrm{O}$ \\
\hline & & & & SPI, M & Fr & Toothache & $\begin{array}{l}\text { Grind the fruit then put on the affected part and } \\
\text { hold with teeth }\end{array}$ & $\mathrm{O}$ \\
\hline & & & & & $\mathrm{R}$ & Evil eye & Pound the root and put it on the fire then sniff it. & $\mathrm{Na}$ \\
\hline \multirow[t]{2}{*}{ M18 } & Carica papaya $*$ & Caricaceae & Papaya & $\mathrm{FO}, \mathrm{M}$ & Fr & Heartburn & Eat the fruit & $\mathrm{O}$ \\
\hline & & & & & $\mathrm{Fr}$ & Granule & Smear on the affected part & Dr \\
\hline \multirow[t]{5}{*}{ M15 } & Carissa spinarum L. \# & Apocynaceae & Agam & FEN, & $\mathrm{R}$ & Snake bite & Pound the root then drink the extract & $\mathrm{O}$ \\
\hline & & & & FIW, M & $\mathrm{R}$ & chest pain & Boiled the root and drunk the extract & $\mathrm{O}$ \\
\hline & & & & & $\mathrm{R}$ & Rheumatism & Pound the root incarceration on the affected part & Dr \\
\hline & & & & & $\mathrm{R}$ & Toothache & Chewing the root & $\mathrm{O}$ \\
\hline & & & & & $\mathrm{R}$ & Abdominal pain & Chewing the root & $\mathrm{O}$ \\
\hline \multirow[t]{2}{*}{ M12 } & Citrus aurantiifolia * & Rutaceae & Lomi & $\mathrm{FO}, \mathrm{M}$ & Fr & Abdominal pain & Squeezed the fruit and drunk its extract. & $\mathrm{O}$ \\
\hline & & & & & $\mathrm{Fr}$ & Vomiting & Squeezed the fruit and drunk the liquid of it & $\mathrm{O}$ \\
\hline
\end{tabular}




\begin{tabular}{|c|c|c|c|c|c|c|c|c|}
\hline M17 & Citrus aurantium $*$ & Rutaceae & Comtate & FO, M & $\mathrm{Fr}$ & Vomiting & Squeezed the fruit and drunk the liquid of it & $\mathrm{O}$ \\
\hline \multirow[t]{2}{*}{ M13 } & Clerodendrum myricoides & Lamiaceae & Miserch & FIW,M & $\mathrm{Al}$ & Asthma & Pound all parts then drink the extract & $\mathrm{O}$ \\
\hline & (Hochst.) Vatke \# & & & & $\mathrm{Al}$ & hemorrhoids & Pound all parts then put on the affected parts & An \\
\hline \multirow[t]{2}{*}{ M16 } & $\begin{array}{l}\text { Clutia abyssinica Jaub. \& } \\
\text { Spach. \# }\end{array}$ & Euphorbiaceae & Fyele fegi & FIW, M & $\mathrm{Al}$ & Cancer & $\begin{array}{l}\text { Pound all parts and extract its decoction then } \\
\text { drink it. }\end{array}$ & $\mathrm{O}$ \\
\hline & & & & & $\mathrm{R}$ & Snake bite & $\begin{array}{l}\text { Pound and extract its decoction. Then .0put on the } \\
\text { decoction on the affected parts. }\end{array}$ & $\operatorname{Dr}$ \\
\hline \multirow[t]{2}{*}{ M23 } & Coffea arabica \# & Rubiaceae & Buna & $\mathrm{FO}, \mathrm{M}$ & $\mathrm{Se}$ & Headache & $\begin{array}{l}\text { Roust the seed and pound; then boil with water. } \\
\text { then drink it }\end{array}$ & $\mathrm{O}$ \\
\hline & & & & & $\mathrm{Se}$ & Diarrhea & $\begin{array}{l}\text { Roust the seed and pound it then mix with milk. } \\
\text { Then drink it }\end{array}$ & $\mathrm{O}$ \\
\hline \multirow[t]{5}{*}{ M22 } & $\begin{array}{l}\text { Croton macrostachyus } \\
\text { Del. \# }\end{array}$ & Euphorbiaceae & Besana & $\begin{array}{l}\text { TIM } \\
\text { FIW, M }\end{array}$ & $\mathrm{L}$ & Allergic & $\begin{array}{l}\text { Rubbed with the liquid of the leaf on the affected } \\
\text { part }\end{array}$ & $\operatorname{Dr}$ \\
\hline & & & & & $\mathrm{L}$ & Wart & Smashed the leaf and put on the affected part & Dr \\
\hline & & & & & $\mathrm{R}$ & Dandruff & Pound its root then put on the affected part & $\operatorname{Dr}$ \\
\hline & & & & & $\mathrm{L}$ & Snake bite & $\begin{array}{l}\text { Extract the liquid by smashing immature leaf and } \\
\text { drink it. The remaining crude put on the affected } \\
\text { part. }\end{array}$ & $\mathrm{O}, \mathrm{Dr}$ \\
\hline & & & & & $\mathrm{L}$ & Eye diseases & $\begin{array}{l}\text { Immature leaf is smashed and put on the affected } \\
\text { eye }\end{array}$ & Oc \\
\hline M21 & Cucumis ficifolius \# & Cucurbitaceae & $\begin{array}{l}\text { Yemider } \\
\text { enmbuye }\end{array}$ & M & $\mathrm{R}$ & Tumor & $\begin{array}{l}\text { Pound the root and incarceration on the affected } \\
\text { parts. }\end{array}$ & Dr \\
\hline M26 & Cucurbita реро $*$ & Cucurbitaceae & Duba & $\mathrm{FO}, \mathrm{M}$ & Fr & Dizziness & Eat the fruit after cook it & $\mathrm{O}$ \\
\hline M27 & Cyphostemma sp.@ & Vitaceae & $\begin{array}{l}\text { Aserkushe } \\
\text { tebtebkushe }\end{array}$ & M & $\mathrm{R}$ & Tumor & The root is pounded and tied on affected part & $\operatorname{Dr}$ \\
\hline M24 & Datura stramonium $\mathrm{L} . *$ & Solanaceae & Astengere & M & $\mathrm{L}$ & Scabies & $\begin{array}{l}\text { The leaf is Smashed and put its extract on the } \\
\text { affected part. }\end{array}$ & $\operatorname{Dr}$ \\
\hline \multirow[t]{2}{*}{ M25 } & Echinops kebericho@ & Asteraceae & Kebercho & M & $\mathrm{R}$ & Evil eye & The dry root is put on the fire then sniff the smoke & $\mathrm{Na}$ \\
\hline & & & & & $\mathrm{R}$ & Diarrhea & The dry root is put on the fire then sniff the smoke & $\mathrm{Na}$ \\
\hline \multirow[t]{2}{*}{ M20 } & Embelia schimperi \# & Myrsinaceae & Enkoko & M & $\mathrm{R}, \mathrm{Fr}$ & Asthma & Dry fruit and root put on the fire and sniffed it & $\mathrm{Na}$ \\
\hline & & & & & $\mathrm{R}, \mathrm{Fr}$ & Tania & $\begin{array}{l}\text { The fruit and root pound then drink by mixing } \\
\text { with water. }\end{array}$ & $\mathrm{O}$ \\
\hline \multirow[t]{2}{*}{ M28 } & Eucalyptus camaldulensis & Myrtaceae & Keye & TIM, & $\mathrm{L}$ & Common cold & Boil in water and fumigated it. & $\mathrm{Na}$ \\
\hline & $*$ & & beharzafe & FIW,M & $\mathrm{L}$ & Pneumonia & Boil in water and fumigated it. & $\mathrm{Na}$ \\
\hline \multirow[t]{2}{*}{ M30 } & Eucalyptus globules & Myrtaceae & Nech & TIM, & $\mathrm{L}$ & Common cold & The leaf is boiled in the water and fumigated it. & $\mathrm{Na}$ \\
\hline & Labill * & & beharzafe & FIW,M & $\mathrm{L}$ & Pneumonia & The leaf is boiled in the water and fumigated it. & $\mathrm{Na}$ \\
\hline M32 & Euphorbia tirucalli L. \# & Euphorbiaceae & Kenchib & M & $\mathrm{R}, \mathrm{La}$ & Rabies & Pound the root then mix with its latex then drink it & $\mathrm{O}$ \\
\hline \multirow[t]{2}{*}{ M35 } & Euphorbia abyssinica \# & Euphorbiaceae & Kulkual & M & $\mathrm{R}, \mathrm{La}$ & Gonorrhea & $\begin{array}{l}\text { Pound the root and mix with its latex then rubbed } \\
\text { on the affected part }\end{array}$ & Dr \\
\hline & & & & & $\mathrm{R}, \mathrm{La}$ & Hemorrhoides & $\begin{array}{l}\text { Pound the root and mix with its latex then rubbed } \\
\text { on the affected part }\end{array}$ & An \\
\hline M36 & Hagenia abyssinica \# & Rosaceae & Koso & M & Fr & Tania & Pound and mix with water and drunk it & $\mathrm{O}$ \\
\hline M31 & Hordeum vulgare \# & Poaceae & Gebse & $\begin{array}{l}\text { FO, } \\
\text { BE,M }\end{array}$ & $\mathrm{L}$ & Dandruff & Pound the leaf and then smear $n$ the affected part & Dr \\
\hline
\end{tabular}




\begin{tabular}{|c|c|c|c|c|c|c|c|c|}
\hline M38 & Kalanchoe petitiana @ & Crassulaceae & Endahula & M & $\mathrm{L}$ & Tumor & $\begin{array}{l}\text { Heat the leaf on the fire the put it on the affected } \\
\text { part }\end{array}$ & Dr \\
\hline \multirow[t]{2}{*}{ M37 } & $\begin{array}{l}\text { Laggera tomentosa } \\
\text { (Sch.Bip. ex A. }\end{array}$ & Asteraceae & Kesekeso & M & $\mathrm{L}$ & Tonsillitis & $\begin{array}{l}\text { Smashed and squeezed the life and extract its } \\
\text { decoction and drink it. }\end{array}$ & $\mathrm{O}$ \\
\hline & Rich.)Olivo@ & & & & $\mathrm{L}$ & $\begin{array}{l}\text { General malaise } \\
\text { "Mich" }\end{array}$ & $\begin{array}{l}\text { Smashed and squeezed the life and extract its } \\
\text { decoction and drink it. }\end{array}$ & $\mathrm{O}$ \\
\hline M34 & Lepidium sativum * & Brassicaceae & Feto & M & $\mathrm{Fr}$ & Abdominal pain & Pound and mix with water and drink it & $\mathrm{O}$ \\
\hline M33 & $\begin{array}{l}\text { Maesa lanceolata Forssk. } \\
\text { \# }\end{array}$ & Myrsinaceae & Kelewa & FIW,M & Fr, Se & Ascaries & Pound and mix water and drink it & $\mathrm{O}$ \\
\hline M29 & $\begin{array}{l}\text { Maytenus arbutifolia (A. } \\
\text { Rich.) Wilczek@ }\end{array}$ & Celastraceae & Atate & FIW, M & $\mathrm{Ba}, \mathrm{R}$ & Evil eye & Put on fire and sniff it & $\mathrm{Na}$ \\
\hline M41 & Musa acuminata \# & Musaceae & Muz & $\mathrm{FO}, \mathrm{M}$ & Fr & Granule & Smear the affected parts with peel of banana. & Dr \\
\hline \multirow[t]{2}{*}{ M39 } & $\begin{array}{l}\text { Ocimum lamiifolium } \\
\text { Hochst. Ex Benth \# }\end{array}$ & Lamiaceae & Damakese & M & $\mathrm{L}$ & Tonsillitis & $\begin{array}{l}\text { Smashed and squeezed the life and extract its } \\
\text { decoction and drink it. }\end{array}$ & $\mathrm{O}$ \\
\hline & & & & & $\mathrm{L}$ & $\begin{array}{l}\text { General malaise } \\
\text { "Mich" }\end{array}$ & $\begin{array}{l}\text { Smashed and squeezed the life and extract its } \\
\text { decoction and drink it. }\end{array}$ & $\mathrm{O}$ \\
\hline M40 & $\begin{array}{l}\text { Olea europaea L.subsp. } \\
\text { cuspidate (Wall. Ex } \\
\text { G.Don \# }\end{array}$ & Oleaceae & Weyera & $\begin{array}{l}\text { FIW,M } \\
\text { FUM }\end{array}$ & $\mathrm{L}$ & Tonsillitis & $\begin{array}{l}\text { Smashed and squeezed the life and extract its } \\
\text { decoction and drink it. }\end{array}$ & $\mathrm{O}$ \\
\hline M44 & Rhamnus prinoides \# & Rhamnaceae & Gesho & $\mathrm{BE}, \mathrm{M}$ & $\mathrm{L}$ & Tonsillitis & $\begin{array}{l}\text { Smashed and squeezed the life and extract its } \\
\text { decoction and drink it. }\end{array}$ & $\mathrm{O}$ \\
\hline M43 & Ruta chalepensis L.\# & Rutaceae & Tenadam & SPI, M & $\mathrm{Fr}$ & Abdominal pain & Pound it and drink it with water & $\mathrm{O}$ \\
\hline M42 & Solanum marginatum L.\# & Solanaceae & Enbuaye & M & $\mathrm{L}$ & nosebleed & Smashed the leaf and insert in the hole of nose & $\mathrm{Na}$ \\
\hline M45 & $\begin{array}{l}\text { Thalictrum } \\
\text { rhynchocarpum Dill. \& } \\
\text { Rich. \# }\end{array}$ & Ranunculaceae & Sere bizue & M & $\begin{array}{l}\mathrm{L} \\
\mathrm{R}\end{array}$ & $\begin{array}{l}\text { Bleeding } \\
\text { Abdominal pain }\end{array}$ & $\begin{array}{l}\text { Smashed and put it on the affected part } \\
\text { Chewing the root }\end{array}$ & $\begin{array}{l}\text { Dr } \\
\text { O }\end{array}$ \\
\hline M2 & Tragia cinerea \# & Euphorbiaceae & Albelabit & M & $\mathrm{R}$ & Tumor & Pound the root and put it on affected part & Dr \\
\hline \multirow[t]{3}{*}{ M1 } & Verbascum sinaiticum & Scrophulariaceae & Yeaheya joro & M & $\mathrm{R}$ & Evil eye & put the root on fire and sniffed it & $\mathrm{Na}$ \\
\hline & Benth. \# & & & & $\mathrm{L}$ & Scabies & $\begin{array}{l}\text { Smashed the leaf and extract its decoction then } \\
\text { spill it on the affected part }\end{array}$ & Dr \\
\hline & & & & & $\mathrm{R}$ & Snake bite & $\begin{array}{l}\text { Pound the root and mix its extract wit water then } \\
\text { drink it }\end{array}$ & $\mathrm{O}$ \\
\hline \multirow[t]{3}{*}{ M3 } & Verbena bonariensis \# & Verbenaceae & Hulegebe & M & $\mathrm{Al}$ & Snake bite & Pound and drink its extract with water & $\mathrm{O}$ \\
\hline & & & & & $\mathrm{L}$ & General malaise "Mich & $\begin{array}{l}\text { Smashed the leaf and extract its decoction then } \\
\text { drink it. }\end{array}$ & $\mathrm{O}$ \\
\hline & & & & & $\mathrm{L}$ & Epilepsy & Put the leaf on the fire and sniffed it & $\mathrm{Na}$ \\
\hline
\end{tabular}

Note: For Ethiopia (Endmic (@), indigenous (\#) and introduced (*)); Plant part (leaf (L), root (R), all part (Al), flower (FL), bulb (BU), sap (Sa), stem (S), latex (La), fruit (Fr), seed (Se) and bark (Ba); Uses (medicinal (M), spice (SPI), food (FO), firewood (FIW), fence (FEN), timber ( TIM), beverage (BE) and fumigation (FUM); Mode of application (oral (O), anal (An), dermal (Dr) andnasal 